\title{
PELATIHAN PENGGUNAAN FIDELIO DALAM KANTOR DEPAN HOTEL BAGI SMK BINUSTA TANGERANG
}

\author{
Wulanmeiaya Wowor ${ }^{1}$, Anastasia Chintya Angelina ${ }^{2}$, Florentina Bustari ${ }^{3}$, Lisya $^{4}$ \\ ${ }^{1}$ Universitas Pelita Harapan \\ ${ }^{2}$ Universitas Pelita Harapan \\ ${ }^{3}$ Universitas Pelita Harapan \\ ${ }^{4}$ Universitas Pelita Harapan
}

wulan.wowor@uph.edu, tanchintya.angelina@ymail.com, verenalisya@yahoo.co.id

\begin{abstract}
Abstrak
Fidelio adalah perangkat lunak komputer yang digunakan sebagai pangkalan data hotel. Perangkat ini mencatat data-data tamu menginap yang meliputi data pribadi, riwayat tinggal, masa tinggal, harga dan tipe kamar, metode pembayaran, kebiasaan tamu, dan data lainnya. Fidelio mencatat seluruh informasi tentang tamu yang dibutuhkan dalam operasional sebuah hotel. Itulah sebabnya menjadi penting bagi karyawan Kantor Depan Hotel untuk memiliki pengetahuan dan keterampilan Fidelio. SMK merupakan sekolah menengah kejuruan yang mempersiapkan peserta didiknya untuk dapat langsung bekerja di industri dengan memberikan berbagai ketrampilan, khususnya ketrampilan bidang perhotelan. Berdasarkan hasil penelitian analisa ketrampilan bidang perhotelan, penggunaan teknologi komputer merupakan salah satu ketrampilan yang dibutuhkan oleh karyawan Kantor Depan Hotel. Kegiatan pengabdian kepada masyarakat ini bertujuan untuk mendeseminasi hasil penelitian tersebut serta memberikan pengetahuan dan ketrampilan penggunaan Fidelio pada siswa SMK. Kegiatan ini dilaksanakan pada 14 Oktober 2016, dengan peserta 21 orang siswa SMK Binusta Tangerang. Metode yang digunakan adalah pelatihan menggunakan Fidelio kepada siswa SMK dengan tahapan pembekalan teori, simulasi penggunaan Fidelio, dan praktik. Hasil dari pelatihan ini dinilai sangat baik oleh peserta karena bertambahnya pengetahuan dan ketrampilan teknologi sebagai bekal untuk bekerja di industri perhotelan. Secara khusus hasil dari pelatihan ini adalah peserta mengerti dan dapat melakukan cara reservasi kamar dan check-in menggunakan Fidelio.
\end{abstract}

Kata Kunci : Fidelio, Kantor Depan, Hotel

\section{PENDAHULUAN}

Kantor Depan merupakan salah satu bagian yang ada pada sebuah hotel. Secara umum, bagian ini memiliki tugas dan tanggung jawab terkait dengan kamar hotel yang meliputi hal pelayanan barang, pesanan kamar, pendaftaran tamu, pelayanan informasi, penyambungan telepon, dan pembayaran kamar tamu (Darsono, 2011).

Menurut Kasavana \& Brooks (1991), bagian ini merupakan pusat aktivitas para tamu di hotel, sehingga bagian ini menjadi amat menentukan kesan pertama pada tamu. Untuk mendapatkan informasi dan layanan selama masa inapnya, para tamu amat mengandalkan bagian ini. Melalui kantor depan, hotel dapat menciptakan lingkungan yang akan memberikan layanan tamu tingkat tinggi. Bagian ini terletak pada area yang paling terlihat di sebuah hotel dengan jumlah kontak tamu terbesar. Itulah sebabnya bagian ini sangat penting dalam menciptakan pengalaman positif bagi

$$
\text { Ekonomi, Sosial, dan Budaya }
$$


tamu hotel dalam hal penjualan kamar yang diperoleh (Walker, 2009).

Dari pernyataan diatas, dapat diketahui bahwa kantor depan menjalankan peran penting dalam operasional hotel. Layanan yang diberikan dapat menentukan reputasi hotel, khususnya melalui layanan penjualan kamar.

Dahmer \& Kahl (2009:2) mendefinisikan layanan sebagai tindakan memenuhi kebutuhan, kemauan, dan keinginan para tamu. Layanan adalah apa yang disediakan pelayan untuk memenuhi harapan para tamu. Pelayanan suatu hotel merupakan faktor utama dalam menarik tamu, di samping lokasi dan fasilitas hotel. Dengan memberikan pelayanan yang baik, maka tamu akan merasa nyaman berada di hotel tersebut sehingga menutup kemungkinan menginap di hotel lain. Layanan di hotel dilakukan oleh karyawan hotel sebagai tenaga kerja yang merupakan aset penting perusahaan, dalam hal ini hotel, yang berperan penting dalam pencapaian tujuan perusahaan (hotel) (Djatmiko, 2016:3).

Andrews (2007:151) mengatakan bahwa kantor depan pada sebuah hotel merupakan departemen yang bertanggung jawab atas penjualan kamar-kamar hotel melalui metode reservasi yang sistematis, diikuti dengan registrasi dan penentuan kamar-kamar untuk para tamu. Sejalan dengan pendapat itu, Chakravati (2008:6) menyatakan bahwa kantor depan hotel adalah departemen administrasi penting dalam sebuah hotel. Chakravati (2008:7) juga menambahkan bahwa kantor depan hotel merupakan titik penjualan utama dan bertanggung jawab untuk tingkat hunian yang lebih tinggi.

Kedua pendapat diatas menyatakan bahwa tanggung jawab terpenting bagian kantor depan adalah layanan penjualan kamar, dimana layanan ini dijalankan oleh karyawan hotel, dalam hal ini karyawan bagian kantor depan.

Untuk menjalankan tugas penjualan ini, karyawan diharuskan memiliki pengetahuan yang luas mengenai informasi internal maupun eksternal hotel. Sebagai penjual, karyawan kantor depan berperan penting dalam mempromosikan segala potensi yang dapat dijual dan nantinya dapat memberikan keuntungan bagi hotel. Karyawan kantor depan juga dituntut untuk dapat mengendalikan situasi dan kondisi emosional yang terjadi, seperti hal nya dalam menangani keluhan tamu. Dengan demikian, beberapa keterampilan diperlukan karyawan kantor depan dalam menjalankan tugas dan tanggung jawabnya.

Menurut Baum \& Devine (2007) ketrampilan penting yang harus dimiliki karyawan kantor depan adalah komunikasi (oral), layanan pelanggan, interpersonal, kerjasama tim, penggunaan peralatan, professional dan etika dasar, komunikasi (tulisan), penggunaan teknologi, kesehatan dan keselamatan, kepemimpinan, pemasaran, akunting, dan isu hukum.

Untuk dapat memberikan layanan yang baik, karyawan perlu diasah ketrampilannya. Selanjutnya Baum \& Devine (2007) menjelaskan bahwa karyawan kantor depan melakukan komunikasi langsung dan dalam posisi penjualan, maka keterampilan karyawan perlu diasah untuk memberikan tingkat kualitas layanan yang lebih tinggi sebagai sarana untuk mencapai diferensiasi kompetitif. Untuk meningkatkan kepuasan tamu, karyawan kantor depan harus mengerti tamu, lalu kenal dengan produk hotel dan mahir dalam pemasaran. Selain itu, karyawan juga harus menunjukkan keterampilan komunikasi dan kontrol emosi.

Salah satu usaha yang dapat dilakukan untuk meningkatkan keterampilan karyawan adalah dengan memberikan pelatihan secara berkesinambungan dan sistematis. Tujuan pelatihan yang diharapkan adalah adanya perbaikan dan peningkatan prestasi kerja karyawan agar tujuan perusahaan dapat tercapai dengan baik.

Dari hasil penelitian analisa ketrampilan karyawan kantor depan hotel, yang dilakukan oleh mahasiswa Fakultas Pariwisata UPH, yang merupakan replikasi dari penelitian Baum \& Devine (2007), diketahui bahwa ada 13 ketrampilan yang dibutuhkan oleh karyawan kantor depan, yaitu (1) komunikasi lisan, (2) kerjasama tim, (3) komunikasi tertulis, (4) pelayanan tamu, (5) kualitas kepemimpinan, (6) standar profesional dan etika, (7) teknik menjual, (8) kesehatan dan keselamatan kerja, (9) antar pribadi, (10) penggunaan teknologi, (11) penggunaan peralatan kantor depan, (12) akuntansi, dan (13) masalah hukum. Berdasarkan hasil penelitian tersebut, keterampilan dalam menggunakan teknologi merupakan salah satu keterampilan yang dibutuhkan karyawan kantor depan.

$$
\text { Ekonomi, Sosial, dan Budaya }
$$


Pentingnya penggunaan teknologi didukung dalam penjelasan Ariyanto (2008) bahwa penggunaan teknologi dalam menunjang operasional membawa pengaruh terhadap hampir semua aspek dalam pengelolaan bisnis, termasuk dalam industri perhotelan. Penggunaan teknologi sangat membantu operasional hotel. Penerapan teknologi pada hotel hendaknya mempertimbangkan kemampuan pemakai sistem teknologi agar teknologi dapat dimanfaatkan secara optimal dan sesuai dengan tugas dan tanggung jawab pemakai yang akan berdampak pada kinerja perusahaan.

Teknologi yang digunakan adalah aplikasi Property Management System (PMS), yaitu aplikasi sistem atau perangkat lunak hotel yang digunakan dalam mengelola sebuah hotel. Menurut Bardi (2011) PMS tidak hanya terbatas pada departemen kantor depan hotel, melainkan tata graha, makanan dan minuman, pemasaran dan penjualan, teknik (engineering), akuntansi dan keamanan. Setiap departemen dalam hotel memiliki peran masingmasing dalam melayani kebutuhan tamu sebelum, selama dan setelah tamu menginap. Oleh sebab itu, sistem harus memudahkan semua karyawan dan tamu hotel. Pemilihan PMS harus disesuaikan dengan tujuan hotel, kebutuhan tamu, dan anggaran hotel. Pada umumnya, sistem ini membantu karyawan kantor depan hotel dalam memproses reservasi, memproses check-in dan check-out, postingan ke rekening tamu, melaksanakan audit malam dan melihat serta mengubah status kamar.

Setiap karyawan yang bekerja di devisi kantor depan dituntut untuk memiliki keterampilan sehingga dapat menggunakan teknologi dan peralatan yang ada. Pengaruh ini memberikan kemudahan dan kelancaran dalam menjalankan tugasnya sebagai karyawan kantor depan. Pada dasarnya penggunaan peralatan di hotel berbedabeda tergantung pada sistem operasional yang digunakan berdasarkan kebijakan masing-masing hotel. Semakin canggih teknologi yang digunakan akan semakin mempermudah terciptanya komunikasi bagi para tamunya.

Fidelio adalah software (perangkat lunak) yang digunakan sebagai database hotel yang mencatat riwayat tamu, harga kamar, tipe kamar, kapan dan berapa lama tamu menginap, apa yang menjadi kebiasaan tamu dan data-data lain yang dapat membantu kantor depan hotel untuk mengetahui karakteristik tamu berdasarkan kebiasaannya menginap di hotel tersebut. Fidelio mencatat keseluruhan informasi mengenai tamu yang dibutuhkan hotel dari mulai proses reservasi. Reservasi penting dalam sebuah hotel karena merupakan bagian dalam produk utama penjualan hotel. Oleh sebab itu, penting bagi hotel memperhatikan setiap detail proses reservasi dengan teliti. Hal ini tentunya harus diawali dengan pengetahuan dan keterampilan yang dimiliki karyawan kantor depan.

SMK Binusta Tangerang merupakan sekolah menengah kejuruan yang memiliki beberapa jurusan seperti Pariwisata dan Akomodasi Perhotelan. Tentunya siswa SMK Binusta dituntut untuk dapat memahami kantor depan hotel beserta dengan tugas dan tanggung jawabnya. Pelatihan ini bertujuan untuk melatih keterampilan murid-murid SMK Binusta Tangerang mengenai keterampilan menggunakan teknologi khususnya menggunakan Fidelio. Pelatihan ini menjadi sarana untuk menambah pengetahuan mereka sebagai bekal untuk bekerja di industri.

Berdasarkan pertimbangan tersebut, prodi Pengelolaan Perhotelan, Fakultas Pariwisata UPH, menyelenggarakan pelatihan penggunaan Fidelio dalam kantor depan hotel bagi SMK Binusta Tangerang.

Tujuan dari program pengabdian kepada masyarakat ini adalah: (1) Diseminasi hasil penelitian mahasiswa Fakultas Pariwisata UPH tentang analisa ketrampilan karyawan kantor depan hotel, (2) Menambah pengetahuan dan ketrampilan aplikasi sistim Fidelio siswa SMK Binusta Tangerang sebagai bekal bekerja di industri perhotelan, khususnya pada bagian kantor depan hotel, (3) Mengasah pengetahuan dan keterampilan mahasiswa Fakultas Pariwisata dalam pengaplikasikan Fidelio.

\section{METODE}

Pelatihan ini merupakan salah satu kegiatan Pengabdian kepada Masyarakat (PkM) dari prodi Pengelolaan Perhotelan, Fakultas Pariwisata UPH, semester ganjil tahun akademik 2016-2017.

Bentuk kegiatan PkM ini adalah pelatihan penggunaan Fidelio yang diselenggarakan pada 14

$$
\text { Ekonomi, Sosial, dan Budaya }
$$


Oktober 2016 di Laboratorium Komputer UPH. Peserta pelatihan adalah siswa SMK Binusta Tangerang berjumlah 21 siswa dengan 2 orang guru pendamping. Pelatihan ini dipimpin oleh 2 orang instruktur yang merupakan mahasiswa tingkat akhir Fakultas Pariwisata UPH. Materi pelatihan adalah menggunakan menu reservasi kamar dan check-in pada sistim Fidelio.

Pelatihan dilaksanakan dalam 3 sesi, yaitu (1) pembekalan teori, (2) simulasi penggunaan, dan (3) praktik. Pada sesi pertama dijelaskan tentang apa dan bagaimana serta tujuan penggunaan Fidelio dalam operasional Kantor Depan Hotel. Sesi selanjutnya penjelasan tentang menu, terminologi, prosedur penggunaan menu reservasi kamar dan check-in yang ada pada Fidelio. Sesi ini disertai dengan simulasi contoh soal. Akhirnya, untuk melengkapi pemahaman peserta, dilakukanlah praktik penggunaan. Pada sesi ini peserta diberi beberapa contoh soal terkait reservasi kamar dan check-in. Kemudian peserta mengerjakan langsung contoh soal tersebut dengan menggunakan Fidelio dengan pendampingan instruktur.

\section{HASIL DAN PEMBAHASAN}

Kegiatan pelatihan dilaksanakan melalui tiga tahapan, yaitu (1) persiapan, (2) pelaksanaan, (3) pelaporan.

Tahap persiapan pelatihan dilakukan sejak Agustus 2016. Pada tahap ini beberapa hal dilakukan. Tim kerja memulainya dengan melakukan survei lapangan untuk mengindentifikasi kebutuhan pelatihan siswa di SMK Binusta Tangerang, serta pembahasan teknis pelaksanaan. Hasil pembahasan selanjutnya dikoordinasikan pada pihak terkait, yaitu prodi Pengelolaan Perhotelan, prodi Usaha Perjalanan Wisata, dan Laboratorium Komputer UPH dalam hal materi dan instruktur, transportasi, logistik, dan ketersediaan laboratorium. Selanjutnya tim kerja memersiapkan proposal kegiatan untuk disetujui oleh prodi Pengelolaan Perhotelan dan LPPM UPH. Setelah proposal disetujui, tim kerja mulai melakukan persiapan materi dan teknis lainnya.
Tahap pelaksanaan kegiatan dibagi atas tiga bagian, yaitu pembukaan, pelaksanaan, dan penutup. Pembukaan dilakukan melalui kata sambutan oleh wakil dari prodi Pengelolaan Perhotelan. Selanjutnya adalah bagian pelaksanaan. Bagian ini terdiri dari tiga sesi, meliputi pembekalan teori, simulasi, dan praktik. Sesi pembekalan teori dibawakan oleh seorang instruktur. Pada peserta dijelaskan apa, tujuan, dan bagaimana Fidelio digunakan, khususnya dalam hal membuat reservasi kamar dan check-in. Setelah itu dilanjutkan dengan sesi simulasi. Seperti halnya sesi pembekalan, sesi ini juga dibawakan oleh instruktur yang mensimulasikan cara membuat reservasi kamar dan check-in menggunakan Fidelio. Sesi terakhir adalah sesi praktik. Pada sesi ini peserta diberi kesempatan untuk berpraktik menggunakan Fidelio. Sesi ini dipimpin oleh instruktur, dengan memberikan beberapa contoh soal reservasi kamar dan check-in. Peserta diminta untuk mengerjakan soal-soal tersebut menggunakan Fidelio. Selama pengerjaan, peserta didampingi oleh beberapa orang pembantu instruktur. Selesai soal dikerjakan, beberapa peserta diminta untuk mempresentasikan hasil kerjanya agar dapat dievaluasi. Sebelum ditutup, peserta juga diminta untuk mengisi lembar evaluasi pelatihan. Menutup pelaksanaan pelatihan, peserta dan guru pendampingnya diberikan sertifikat pelatihan, yang dilanjutkan dengan foto bersama.

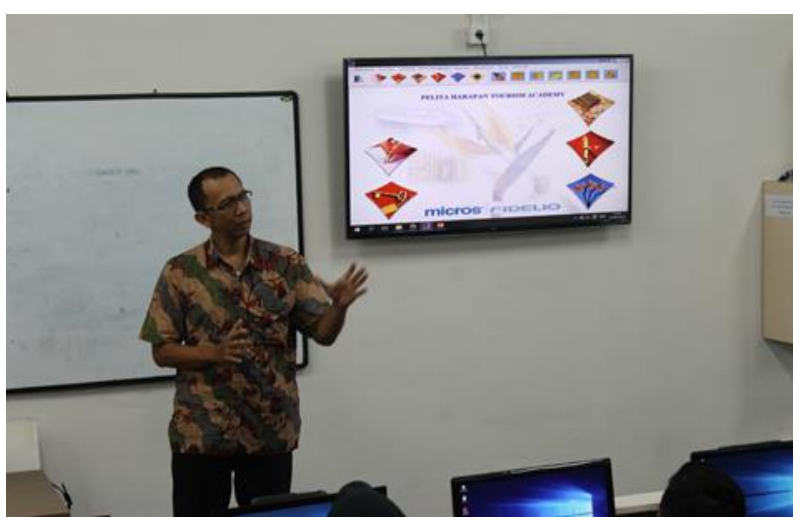

Gambar 1. Pembukaan Pelatihan 


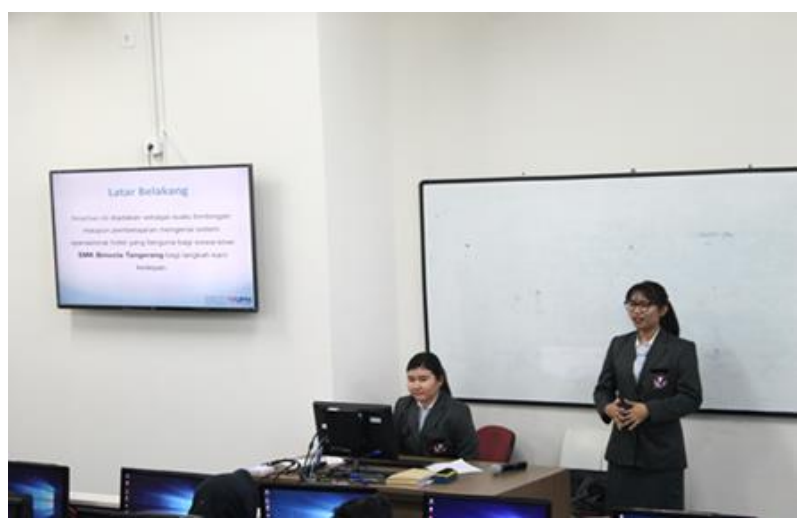

Gambar 2. Penjelasan Instruktur

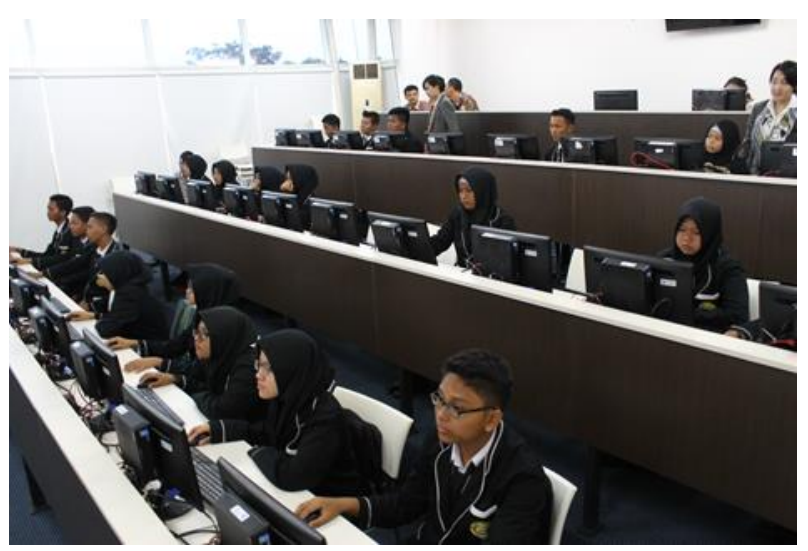

Gambar 3. Sesi Praktik

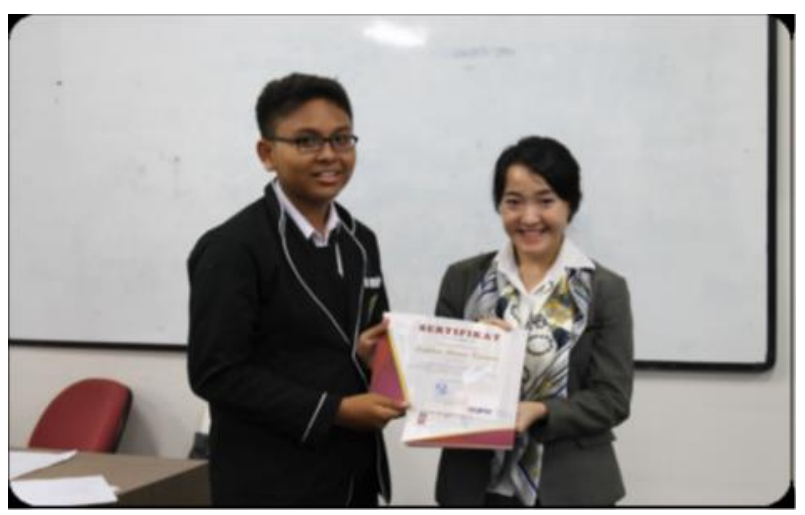

Gambar 4. Penyerahan Sertifikat

Pada tahapan akhir, tim kerja menyusun laporan kegiatan sebagai pertanggungjawaban bahwa pelatihan telah selesai dilaksanakan. Laporan yang disusun dilengkapi dengan berita acara yang ditanda tangani pihak SMK Binusta Tangerang dan Fakultas Pariwisata UPH.

Melengkapi pelaksanaan pelatihan, tim kerja melakukan evaluasi. Evaluasi dilakukan untuk mengetahui tercapai tidaknya tujuan dan manfaat kegiatan PkM ini. Selain itu juga untuk mengukur sejauh mana kegiatan ini dilaksanakan dan mendapatkan umpan balik peserta dalam rangka peningkatan pelaksanaan kegiatan di waktu yang akan datang.

Evaluasi yang dilakukan berupa kuesioner yang berisikan sejumlah pertanyaan-pertanyaan indikator yang berhubungan dengan pelaksanaan kegiatan. Kuesioner ini diisi oleh semua peserta dengan menyatakan penilaiannya atas pertanyaan indikator: (1) Sangat tidak baik, (2) Tidak baik, (3) Baik, (4) Sangat baik. Adapun hasil dari evaluasi adalah sebagai berikut:

\section{Tabel 1. Hasil Evaluasi Pelaksanaan Pelatihan}

\begin{tabular}{|c|l|l|}
\hline No & \multicolumn{1}{|c|}{ Indikator } & \multicolumn{1}{c|}{ Hasil } \\
\hline 1 & Tujuan pelatihan & Sangat baik $(76.19 \%)$ \\
\hline 2 & Materi pelatihan & Sangat baik $(90.47 \%)$ \\
\hline 3 & Fasilitas pelatihan & Sangat baik $(95.23 \%)$ \\
\hline 4 & Instruktur & Sangat baik $(85.71 \%)$ \\
\hline 5 & Pelaksanaan & Sangat baik $(90.47 \%)$ \\
\hline 6 & Manfaat pelatihan & Sangat baik (80.95\%) \\
\hline 7 & Efektifitas pelatihan & Sangat baik (85.71\%) \\
\hline 8 & $\begin{array}{l}\text { Tindak lanjut } \\
\text { pelatihan }\end{array}$ & Sangat baik $(80.95 \%$ \\
\hline
\end{tabular}

Tujuan Pelatihan mencakup hal penambahan pengetahuan mengenai Fidelio bagi peserta, mengasah pengetahuan dan keterampilan mahasiswa Fakultas Pariwisata di bidang Fidelio dan meningkatkan kerja sama antara Fakultas Pariwisata UPH dengan SMK Binusta Tangerang. Tujuan ini dinilai tercapai dengan skor $76.19 \%$ (sangat baik). Peserta menyatakan bahwa mereka dapat pengetahuan tentang Fidelio karena sebelum pelatihan, peserta tidak mengetahuinya. Hal itu juga berarti bahwa ada peningkatan pengetahuan dan ketrampilan Fidelio mahasiswa Fakultas Pariwisata 
karena berhasil mentranformasikan pengetahuan dan ketrampilannya pada peserta. Dikarenakan adanya pengetahuan dan ketrampilan baru yang di dapat dari pelatihan ini, peserta berharap akan adanya pelatihan ketrampilan yang berbeda. Hal ini tentunya dapat meningkatkan kerjasama antar kedua institusi.

Materi Pelatihan mencakup tata cara reservasi dan check-in pada sistem Fidelio dalam kantor depan hotel. Hasil dari penilaian Materi Pelatihan adalah sangat baik dengan skor $90.47 \%$. Kedua materi pelatihan tersebut sangat bermanfaat dan sesuai dengan kurikulum operasional yang ada di SMK Binusta Tangarenag.

Fasilitas Pelatihan dinilai sangat baik dengan skor 95.23\%. Tempat pelatihan serta peralatan dan perlengkapan yang digunakan sudah amat memadai. Semua komputer telah dilengkapi dengan sistem Fidelio sehingga peserta dapat mempraktikan materi pada komputer masingmasing.

Dalam hal Instruktur selaku penyampai materi, peserta menilai sangat baik dengan skor $85.71 \%$. Instruktur dapat menyampaikan materi dengan baik, bersikap komunikatif, ramah, dapat membantu peserta, dan menguasai materi pelatihan.

Pelaksanaan pelatihan juga dinilai sangat baik dengan skor $90.47 \%$. Tidak keluhan yang diajukan sehubungan dengan pelaksanaan. Peserta merasa senang dan antusias selama pelatihan berlangsung.

Peserta sangat merasakan manfaat dalam pelatihan ini. Hasil penilaian adalah sangat baik dengan skor $80.95 \%$. Para peserta mengaku menjadi mengerti cara reservasi dan check in pada Fidelio dengan baik dan benar setelah mengikuti pelatihan.

Pelatihan juga telah dilakukan dengan efektif. Hal ini dapat diketahui dari hasil penilaian yaitu sangat baik dengan skor $85.71 \%$. Pilihan materi dan cara penyampaian materi yang didahului dengan pengenalan teori, dilanjutkan dengan simulasi penggunaan dan pembuatan, dan diakhiri dengan praktik, menjadikan peserta memahami dan dapat mengaplikasikan Fidelio dengan cepat dan mudah. Hal itu diperkuat dengan hasil presentasi peserta yang menggambarkan bahwa peserta telah mampu membuat reservasi kamar dan check-in menggunakan Fidelio.

Penilaian terakhir yang diberikan adalah mengenai tindak lanjut pelatihan yang juga dinilai sangat baik denga skor $80.95 \%$. Hal ini mencakup pengembangan materi pelatihan yang baik serta adanya pelatihan yang diharapkan untuk dilakukan secara berkelanjutan.

Dari hasil evaluasi, dapat diketahui bahwa semua indikator mendapat penilaian sangat baik. Dengan demikian dikatakan bahwa kegiatan pelatihan sudah dilaksanakan oleh prodi Pengelolaan Perhotelan Fakultas Pariwisata UPH dan diterima oleh SMK Binusta Tangerang dengan baik.

\section{KESIMPULAN}

Kesimpulan yang dapat diambil dari kegiatan ini adalah (1) Diseminasi hasil penelitian tentang analisa ketrampilan bidang perhotelan, khususnya penggunaan teknologi komputer telah terlaksana dan diterima dengan antusias oleh peserta; (2) Pengetahuan peserta tentang Fidelio bertambah; (3) Peserta dapat memahami reservasi kamar dan check-in pada Fidelio; (4) Peserta dapat membuat reservasi kamar menggunakan Fidelio; (5) Peserta dapat menangani check-in menggunakan Fidelio.

\section{UCAPAN TERIMAKASIH}

Ucapan terimakasih disampaikan kepada (1) SMK Binusta Tangerang yang telah mengikutsertakan siswanya sebagai peserta pelatihan dalam kegiatan Pengabdian kepada Masyarakat dengan no. PM-062-STPPH/IX/2016; (2) Program studi Pengelolaan Perhotelan, dan (3) Universitas Pelita Harapan yang telah memfasilitasi kegiatan ini.

\section{REFERENSI}

Andrews, S. (2007). Textbook of Front Office Management and Operations. New Delhi: Tata McGraw- Hill.

Ariyanto, D. (2008). Pengaruh Efektivitas Penggunaan dan Kepercayaan Teknologi Sistem Ekonomi, Sosial, dan Budaya

1125 
Informasi Terhadap Kinerja Individual. Jurnal Ilmiah Akuntansi dan Bisnis, 3(1).

Bardi, J. A. (2011). Hotel Front Office Management. 5th edition. Hoboken, New Jersey: John Wiley \& Sons, Inc.

Baum, T. \& Devine, F. (2007). Skills and training in the hotel sector: The case of front office emplotment in Nothern Ireland. Tourism and Hospitality Research (2007), No. 7, pp.269- 280.

Chakravati, B. K. (2008). Concept of Front Office Management. New Delhi: S. B. Nangia.

Darsono, A. (2011). Front Office Hotel. Jakarta: Grasindo.

Dahmer, S.J. dan Kahl, K.W. (2009). Restaurant Service Basics. 2nd edition. New Jersey: Wiley.

Djatmiko, R. D. (2016). Keselamatan dan Kesehatan Kerja. Yogyakarta: Deepublish.

Kasavana, M. \& Brooks, R. 1991. Managing Front Office Operations. Michigan: Educational Institute of the American Hotel and Motel Association.

Walker, J. (2009). Introduction to Hospitality. 5th Ed. New Jersey: Pearson Prentice Hall.

\section{LAMPIRAN}

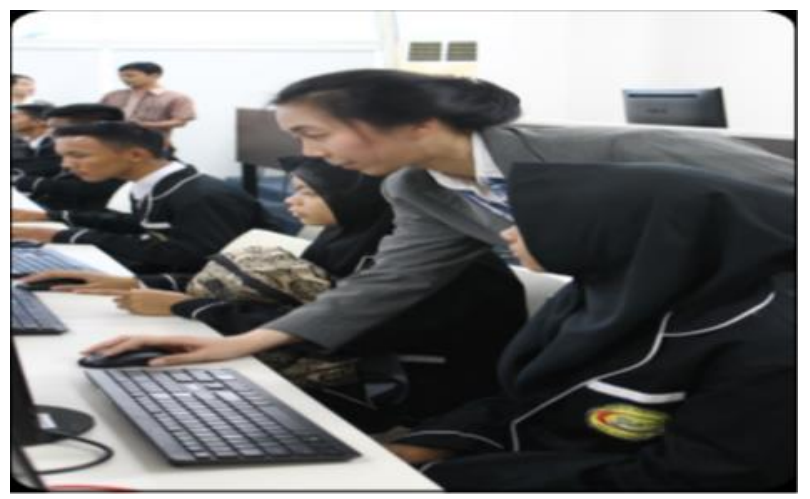

Gambar 5. Pendampingan Peserta (A)

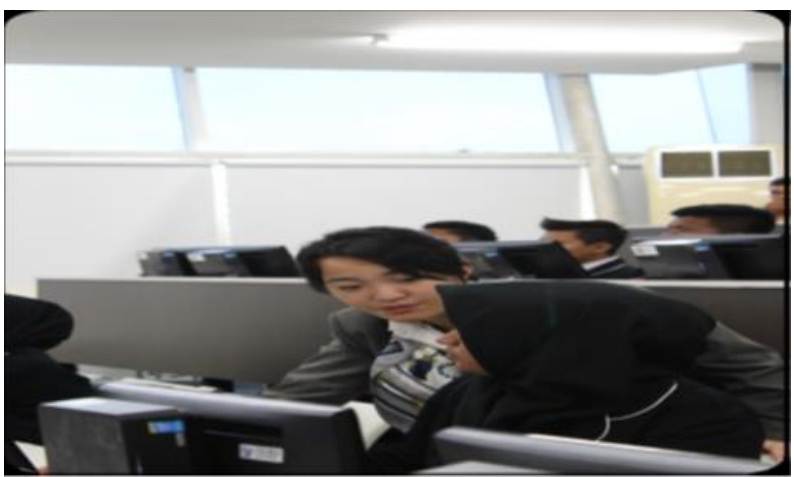

Gambar 6. Pendampingan Peserta (B)

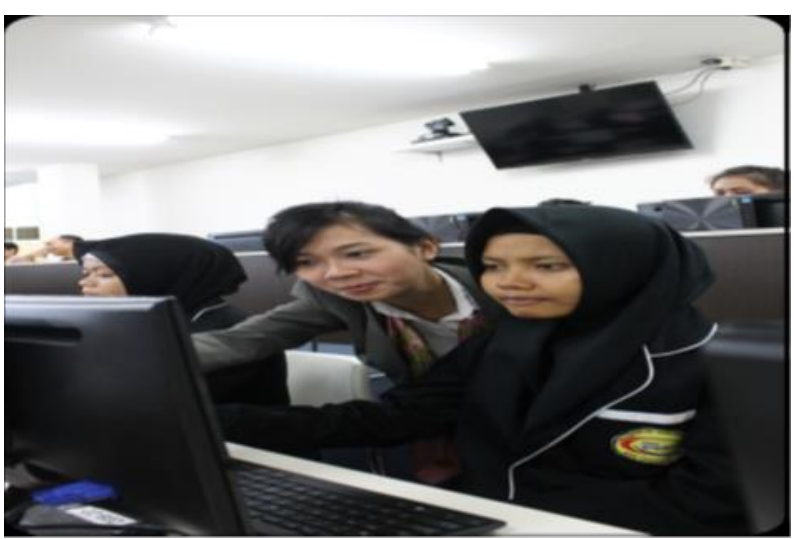

Gambar 7. Pendampingan Peserta (C)

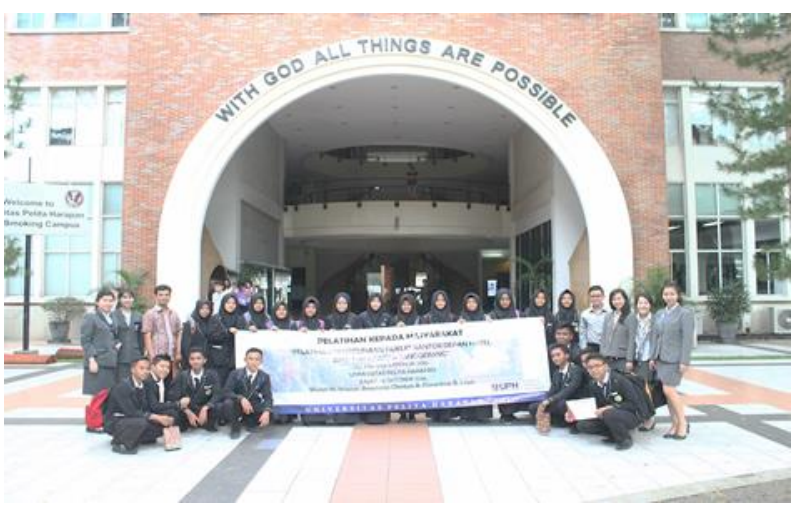

Gambar 8. Foto Bersama 


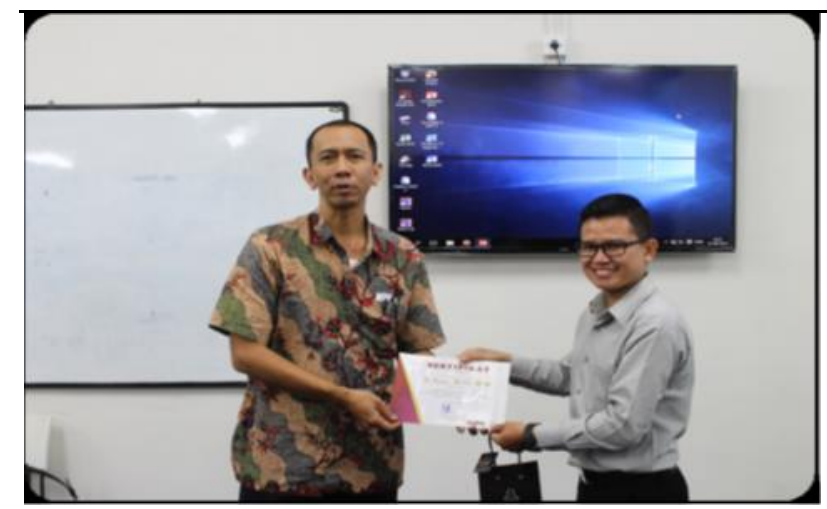

Gambar 9. Penyerahan Sertifikat Guru 